Dinamika Kesehatan Jurnal Kebidanan dan Keperawatan Vol 10 No. 2 Desember 2019 ( ISSN: 2086-3454 EISSN: 2549-4058) url: http://ojs.dinamikakesehatan.unism.ac.id DOI: https://doi.org/10.33859/dksm.v10i2

Faktor- Faktor Yang Berhubungan Dengan Kejadian Perdarahan Postpartum Pada Ibu Bersalin di Wilayah Kerja Dinas Kesehatan Kabupaten Merangin

\title{
Faktor- Faktor Yang Berhubungan Dengan Kejadian Perdarahan Postpartum Pada Ibu Bersalin di Wilayah Kerja Dinas Kesehatan Kabupaten Merangin
}

\author{
Defi Uprianti Bakri1, Syahredi S. Adenin2, Irza Wahid3 \\ 1,2,3 Fakultas Kedokteran Universitas Andalas Padang Komplek Kampus Unand, Limau Manis, \\ Kec. Pauh, Kota Padang, Sumatera Barat 25176 \\ *correspondence author: Telepon:081274740606, E-mail: deffi_alfatih@yahoo.co.id
}

DOI: https://doi.org/10.33859/dksm.v10i2.512

\begin{abstract}
Abstrak
Latar belakang:Penyebab kematian ibu terbesar yaitu perdarahan, lebih dari separuh jumlah seluruh kematian ibu terjadi karena perdarahan postpartum. Perdarahan postpartum dapat juga disebabkan oleh beberapa faktor risiko seperti umur, jumlah paritas, jarak antar kelahiran.

Tujuan: Tujuan penelitian ini adalah untuk mengetahui faktor-faktor yang berhubungan dengan kejadian perdarahan postpartum.

Metode: metode analitik restropektif dengan pendekatan Case Control Study terhadap 58 ibu yang bersalin di wilayah kerja dinas kesehatan Kabupaten Merangin yang terdiri dari kasus dan control. Sampel dipilih secara simple random sampling. Analisis statistik menggunakan uji Chi-Square untuk dapat menyimpulkan adanya hubungan dua variabel bermakna atau tidak bermakna.

Hasil: Hasil uji chi square menunjukkan terdapat hubungan yang bermakna antara umur(p: 0,001, OR: 3,63; CI: 1,686-7,843), paritas (p: 0,000, OR: 5,971; CI: 2,658-13,413), jarak kelahiran (p: 0,000, OR: 5,388; CI: 2,433-11,933).

Simpulan: dari Hasil penelitian ini yaitu ibu hamil dengan umur, paritas dan jarak kelahiran berisiko akan meningkatkan kejadian perdarahan postpartum. Oleh karena itu diharapkan kepada tenaga kesehatan untuk dapat meningkatkan edukasi kepada masyarakat tentang keluarga berencana dengan jumlah yang aman.
\end{abstract}

Kata Kunci : Umur, Paritas, Jarak kelahiran, Perdarahan Post Partum 
Dinamika Kesehatan Jurnal Kebidanan dan Keperawatan Vol 10 No. 2 Desember 2019 ( ISSN: 2086-3454 EISSN: 2549-4058) url: http://ojs.dinamikakesehatan.unism.ac.id DOI: https://doi.org/10.33859/dksm.v10i2

Faktor- Faktor Yang Berhubungan Dengan Kejadian Perdarahan Postpartum Pada Ibu Bersalin di Wilayah Kerja Dinas Kesehatan Kabupaten Merangin

\title{
Factors related to the incidence of Postpartum Bleeding To Maternity Mothers in the Working Area of Merangin District Health Office
}

\begin{abstract}
The biggest cause of maternal mortality is bleeding, more than half the total number of maternal deaths occurs due to postpartum bleeding. Postpartum bleeding can also be caused by several risk factors such as age, number of parity, distance between births. The purpose of this research is to know the factors related to the incidence of postpartum bleeding. This research uses a method of analytical methods with the approach Case Control Study of 58 mothers who maternity in the work area of Merangin District health Office consisting of cases and Control. Samples were selected by simple random sampling. Statistical analysis using the Chi-Square test can conclude the relationship between two or no meaningful variables. The Chi square test results show there is a meaningful relationship between age (p: 0.001, OR: 3.63; CI: 1,686-7,843), Parity (p: 0.000, OR: 5.971; CI: 2,658-13,413), Birth distance (p: 0.000, OR: 5.388; CI: 2,433-11,933). The conclusion of this research is that pregnant women with age, parity and the risk of birth distance will increase the incidence of postpartum bleeding. Therefore it is expected to health personnel to be able to improve education to the community about family planning with a safe amount.
\end{abstract}

Keywords: Age, Parity, Birth Distance, Post Partum bleeding

\section{Pendahuluan}

Keberhasilan upaya kesehatan ibu, di antaranya dapat dilihat dari indikator Angka Kematian Ibu (AKI). Indikator ini tidak hanya mampu menilai program kesehatan ibu, tetapi juga mampu menilai derajat kesehatan masyarakat (Kemenkes RI, 2017). Menurut World Health Organization (WHO) penyebab utama kematian ibu pada wanita umur produktif di negara berkembang karena komplikasi selama kehamilan dan persalinan.
Kejadian komplikasi kehamilan yang dialami wanita di negara sedang

berkembang 300 kali lebih besar dibandingkan negara maju, di Asia Tenggara rata-rata setiap hari terjadi 1,500 kematian ibu akibat komplikasi kehamilan (WHO, 2014).

$$
\text { Penurunan AKI di Indonesia terjadi }
$$
sejak tahun 1991 sampai dengan 2007, yaitu dari 390/100.000 kelahiran hidup menjadi 228/100.000 kelahiran hidup. Survey Demografi dan Kesehatan Indoneiaa (SDKI) 
Dinamika Kesehatan Jurnal Kebidanan dan Keperawatan Vol 10 No. 2 Desember 2019 ( ISSN: 2086-3454 EISSN: 2549-4058)

url: http://ojs.dinamikakesehatan.unism.ac.id DOI: https://doi.org/10.33859/dksm.v10i2

Faktor- Faktor Yang Berhubungan Dengan Kejadian Perdarahan Postpartum Pada Ibu Bersalin di Wilayah Kerja Dinas Kesehatan Kabupaten Merangin

tahun 2012 menunjukkan peningkatan AKI yang signifikan yaitu menjadi 359 kematian ibu per 100.000 kelahiran hidup. AKI kembali menunjukkan penurunan menurut hasil Riset Kesehatan Dasar (Riskesdas) AKI di Indonesia sebesar 305/100.000 kelahiran hidup. Hal ini masih jauh dari target SDG's yakni di bawah 70 per 100.000 kelahiran hidup pada tahun 2030(Kemenkes RI, 2017).

Kematian ibu dapat disebabkan karena komplikasi kehamilan, komplikasi persalinan, komplikasi nifas, riwayat penyakit ibu, dan riwayat $\mathrm{KB}$, serta keterlambatan rujukan (Fibriana, 2007). Penyebab kematian ibu dapat dikategorikan penyebab langsung dan tidak langsung. Penyebab langsung terkait dengan aspek medis yaitu akibat komplikasi selama dan setelah kehamilan, persalinan dan nifas (Kemenkes RI, 2015).

Menurut Profil Kesehatan Indonesia tahun 2014 penyebab kematian ibu terbesar yaitu perdarahan $(30,3 \%)$, perdarahan postpartum merupakan penyebab tersering dari keseluruhan kematian akibat perdarahan obstetrik. Penyebab lain yaitu hipertensi dalam kehamilan $(27,1 \%)$, infeksi $(7,3 \%)$, dan lain-lain. Penyebab kematian ibu tidak langsung seperti kondisi penyakit kanker, ginjal, jantung atau penyakit lain yang diderita ibu sebesar (35,3\%) (Kemenkes RI, 2015).

Menurut data di berbagai negara paling sedikit seperempat dari seluruh kematian ibu disebabkan oleh perdarahan, proporsinya berkisar antara dari $10 \%$ sampai $60 \%$ (PP dan KPA, 2010). Perdarahan postpartum merupakan pengeluaran darah lebih dari $500 \mathrm{ml}$ pada persalinan pervaginam dan lebih dari $1000 \mathrm{ml}$ pada seksio sesarea setelah bayi dilahirkan (Chunningham, 2012).

Prevalensi perdarahan postpartum berkisar antara 7,2\% terjadi di Negara Oceania hingga 25,7\% di Afrika. Prevalensi perdarahan postpartum tertinggi di Afrika pada 5,1\% dan terendah di Asia pada 1,9\% (Calvert et al., 2012). Diperkirakan ada 14 juta kasus perdarahan dalam kehamilan setiap tahunnya paling sedikit 128.000 wanita mengalami perdarahan sampai meninggal. Amerika Serikat di tahun 2005-2008, prevalensi perdarahan postpartum meningkat 
Dinamika Kesehatan Jurnal Kebidanan dan Keperawatan Vol 10 No. 2 Desember 2019 ( ISSN: 2086-3454 EISSN: 2549-4058)

url: http://ojs.dinamikakesehatan.unism.ac.id DOI: https://doi.org/10.33859/dksm.v10i2

Faktor- Faktor Yang Berhubungan Dengan Kejadian Perdarahan Postpartum Pada Ibu Bersalin di Wilayah Kerja Dinas Kesehatan Kabupaten Merangin

$28 \%$ terjadi di rumah sakit dan $19 \%$ terjadi di rumah (Polly et al., 2009).

Perdarahan postpartum juga disebabkan oleh beberapa faktor risiko yaitu umur, jumlah paritas, jarak antar kelahiran, riwayat persalinan sebelumnya, lama partus, lama lepasnya plasenta, anemia, pengetahuan ibu, perilaku ibu, kunjungan ANC dan faktor fasilitas pelayanan kesehatan (Pardosi, et al, 2006).

Kejadian perdarahan postpartum primer pada ibu bersalin sebesar 45\% (Selina, 2017). Menurut penelitian Assarag dkk (2013) komplikasi nifas meliputi kesehatan mental, infeksi genital, masalah payudara, dan pendarahan.

Masalah umur, paritas dan jarak kehamilan atau yang dikenal dengan " $4 \mathrm{~T}$ " yaitu terlalu tua, terlalu muda, terlalu banyak dan terlalu dekat (Manuaba, 2012). Hal ini didukung hasil penelitian dari Selina (2017) di Surabaya mengatakan bahwa adanya hubungan yang signifikan antara umur ibu dengan perdarahan post partum Odds Ratio $(\mathrm{OR})=7,347$ yang berarti bahwa ibu dengan umur yang berisiko $(<20$ tahun dan $>35$ tahun) memiliki risiko 7,347 kali lebih besar dibandingkan umur yang tidak berisiko (2035 tahun). Karena di umur ibu $<20$ tahun reproduksi seorang wanita belum berkembang dengan sempurna sehingga belum siap untuk hamil dan melahirkan, sedangkan pada umur $\geq 35$ tahun terjadi kemunduran yang progresif dari endometrium yang mempengaruhi kekuatan kontraksi pada saat persalinan dan setelah persalinan (Saadah, et al, 2016).

Berdasarkan Profil Dinas Kesehatan Propinsi Jambi diketahui bahwa angka kematian di Provinsi Jambi tahun 2016 sebesar 29/100.000 kelahiran hidup (Dinkes Jambi, 2016). Sedangkan di Kabupaten Merangin angka kematian ibu yang dilaporkan 70/100.000 kelahiran hidup. (Dinkes Merangin, 2018).

Berdasarkan studi pendahuluan yang dilakukan di wilayah kerja Dinas Kesehatan Kabupaten Merangin tahun 2017, diketahui bahwa jumlah persalinan yang ditolong oleh tenaga kesehatan di Kabupaten Merangin sebanyak 7403 orang dengan kasus 
Dinamika Kesehatan Jurnal Kebidanan dan Keperawatan Vol 10 No. 2 Desember 2019 ( ISSN: 2086-3454 EISSN: 2549-4058)

url: http://ojs.dinamikakesehatan.unism.ac.id DOI: https://doi.org/10.33859/dksm.v10i2

Faktor- Faktor Yang Berhubungan Dengan Kejadian Perdarahan Postpartum Pada Ibu Bersalin di Wilayah Kerja Dinas Kesehatan Kabupaten Merangin

perdarahan $1,82 \%$, ditahun 2018 mengalami peningkatan kasus perdarahan sebanyak 2,18\% dari 7096 ibu bersalin, yang terbagi atas 27 Puskesmas.

Berdasarkan latar belakang diatas, maka peneliti akan meneliti faktor - faktor yang berhubungan dengan kejadian perdarahan post partum pada ibu bersalin di wilayah kerja Dinas Kesehatan Kabupaten Merangin.

\section{Bahan dan Metode}

Penelitian ini menggunakan metode analitik restropektif dengan pendekatan Case Control Study terhadap 58 ibu yang bersalin mengalami perdarahan postpartum sebagai kasus dan 58 ibu bersalin yang tidak mengalami perdarahan postpartum sebagai kontrol di wilayah kerja dinas kesehatan Kabupaten Merangin. Sampel dipilih secara simple random sampling sesuai dengan kriteria inklusi dan eksklusi Analisis statistik menggunakan uji Chi-Square untuk dapat menyimpulkan adanya hubungan dua variabel bermakna atau tidak bermakna.

\section{Hasil Penelitian}

Tabel 1.Hubungan umur dengan Kejadian Perdarahan Post Partum di Pada Ibu Bersalin di Wilayah Kerja Dinas Kesehatan Kabupaten Merangin

\begin{tabular}{|c|c|c|c|c|c|c|c|}
\hline \multirow[t]{3}{*}{ Umur } & \multicolumn{4}{|c|}{$\begin{array}{c}\text { Kejadian Perdarahan } \\
\text { postpartum }\end{array}$} & \multirow{2}{*}{\multicolumn{2}{|c|}{ Total }} & \multirow[t]{3}{*}{$\mathbf{p}$} \\
\hline & \multicolumn{2}{|c|}{ Kasus } & \multicolumn{2}{|c|}{ Kontrol } & & & \\
\hline & $\mathbf{f}$ & $\%$ & $\mathbf{f}$ & $\%$ & $\mathbf{f}$ & $\%$ & \\
\hline Berisiko & 40 & 69,0 & 22 & 37,9 & 62 & 53,4 & 0,000 \\
\hline $\begin{array}{l}\text { Tidak } \\
\text { Berisiko }\end{array}$ & 18 & 31,0 & 36 & 62,1 & 54 & 46,6 & \\
\hline Total & 58 & 100 & 58 & 100 & 116 & 100 & \\
\hline
\end{tabular}

Berdasarkan tabel 1 dapat diketahui bahwa umur berisiko $(<20$ tahun dan $>35$ tahun) sebanyak 40 responden $(69,0 \%)$ lebih besar dibandingkan umur tidak berisiko (20 tahun - 35 tahun) pada kelompok kasus sebanyak 18 responden $(31,0 \%)$ sedangkan pada kelompok kontrol umur berisiko $(<20$ tahun dan $>35$ tahun) sebanyak 22 responden $(37,9 \%)$ lebih besar dibandingkan dengan umur tidak berisiko (20 tahun - 35 tahun) sebanyak 36 responden $(62,1 \%)$.

Hasil uji statistik Chi Square dengan nilai $p$ value adalah 0,001 menunjukkan ada hubungan yang bermakna antara umur dengan kejadian perdarahan post partum, dengan nilai $\mathrm{OR}=3.636(\mathrm{CI}: 1.686-7.843)$, artinya resiko untuk mengalami perdarahan 
Dinamika Kesehatan Jurnal Kebidanan dan Keperawatan Vol 10 No. 2 Desember 2019 ( ISSN: 2086-3454 EISSN: 2549-4058)

url: http://ojs.dinamikakesehatan.unism.ac.id DOI: https://doi.org/10.33859/dksm.v10i2

Faktor- Faktor Yang Berhubungan Dengan Kejadian Perdarahan Postpartum Pada Ibu Bersalin di Wilayah Kerja Dinas Kesehatan Kabupaten Merangin

pasca persalinan pada kelompok umur $<20$ tahun dan kelompok umur $>35$ tahun adalah 3.636 kali lebih besar dibandingkan dengan kelompok umur antara 20-35 tahun.

Tabel 2. Hubungan Paritas Dengan Kejadian Perdarahan Post Partum Pada Ibu Bersalin di Wilayah Kerja Dinas Kesehatan Kabupaten Merangin

\begin{tabular}{|c|c|c|c|c|c|c|c|}
\hline \multirow[t]{3}{*}{ Paritas } & \multicolumn{4}{|c|}{$\begin{array}{l}\text { Kejadian Perdarahan } \\
\text { postpartum }\end{array}$} & \multirow{2}{*}{\multicolumn{2}{|c|}{ Total }} & \multirow[t]{3}{*}{$\mathrm{p}$} \\
\hline & \multicolumn{2}{|c|}{ Kasus } & \multicolumn{2}{|c|}{ Kontrol } & & & \\
\hline & $\mathrm{f}$ & $\%$ & $f$ & $\%$ & $\mathrm{f}$ & $\%$ & \\
\hline Berisiko & 44 & 75,9 & 20 & 34,5 & 64 & 55,2 & 0,000 \\
\hline Tidak & 14 & 24,1 & 38 & 65,5 & 52 & 44,8 & \\
\hline Berisiko & & & & & & & \\
\hline Total & 58 & 100 & 58 & 100 & 116 & 100 & \\
\hline
\end{tabular}

$O R=5.971(C I: 2.658-13.413)$

Berdasarkan tabel 2 dapat diketahui bahwa paritas berisiko (1 dan >4) sebanyak 44 responden $(75,9 \%)$ lebih besar dibandingkan paritas tidak berisiko (2 dan 3) pada kelompok kasus sebanyak 14 responden $(24,1 \%)$ sedangkan pada kelompok kontrol paritas tidak berisiko (2 dan 3) sebanyak 38 responden $(65,5 \%)$ lebih besar dibandingkan dengan paritas berisiko (1 dan >4) sebanyak 20 responden $(34,5 \%)$.

Hasil uji statistik Chi-Square dengan nilai $p$ Value adalah 0,000 menunjukkan ada hubungan yang bermakna antara paritas dengan kejadian perdarahan post partum.
Dengan nilai $\mathrm{OR}=5.971$ (CI : 2.658-13.413), artinya risiko untuk mengalami perdarahan post partum pada kelompok paritas berisiko (1 dan >4) adalah 5.971 kali lebih besar dibandingkan dengan kelompok paritas tidak berisiko (2 dan 3 ).

Tabel 3. Hubungan Jarak Kehamilan Dengan Kejadian Perdarahan Post Partum Pada Ibu Bersalin di Wilayah Kerja Dinas Kesehatan Kabupaten Merangin

\begin{tabular}{lccccccc}
\hline Jarak & \multicolumn{3}{c}{$\begin{array}{c}\text { Kejadian Perdarahan } \\
\text { postpartum }\end{array}$} & Total & \multirow{2}{*}{$\begin{array}{c}\mathrm{p} \\
\text { value }\end{array}$} \\
\cline { 2 - 5 } & \multicolumn{2}{c}{ Kasus } & \multicolumn{2}{c}{ Kontrol } & & & \\
\cline { 2 - 6 } & $\mathrm{F}$ & $\%$ & $\mathrm{f}$ & $\%$ & $\mathrm{f}$ & $\%$ & \\
\hline Berisiko & 39 & 67,2 & 16 & 27,6 & 55 & 47,4 & 0,000 \\
Tidak & 19 & 32,8 & 42 & 72,4 & 61 & 52,6 & \\
Berisiko & & & & & & & \\
\hline Total & 58 & 100 & 58 & 100 & 116 & 100 & \\
\hline OR $=5.388(\mathrm{CI}: 2.433-11.933)$ & & &
\end{tabular}

Berdasarkan tabel 3 dapat diketahui bahwa jarak kehamilan berisiko ( $<2$ tahun) sebanyak 39 responden $(67,2 \%)$ lebih besar dibandingkan jarak kehamilan tidak berisiko ( $\geq 2$ tahun) pada kelompok kasus sebanyak 19 responden $(32,8 \%)$ sedangkan pada kelompok kontrol jarak kehamilan tidak berisiko ( $\geq 2$ tahun) sebanyak 42 responden $(72,4 \%)$ lebih besar dibandingkan dengan jarak kehamilan berisiko $(<2$ tahun $)$ sebanyak 16 responden $(27,6 \%)$. 
Dinamika Kesehatan Jurnal Kebidanan dan Keperawatan Vol 10 No. 2 Desember 2019 ( ISSN: 2086-3454 EISSN: 2549-4058)

url: http://ojs.dinamikakesehatan.unism.ac.id DOI: https://doi.org/10.33859/dksm.v10i2

Faktor- Faktor Yang Berhubungan Dengan Kejadian Perdarahan Postpartum Pada Ibu Bersalin di Wilayah Kerja Dinas Kesehatan Kabupaten Merangin

Hasil uji statistik Chi-Square dengan nilai pvalue adalah 0,000 , menunjukkan ada hubungan yang bermakna antara jarak kehamilan dengan kejadian perdarahan post partum. Dengan nilai OR $=5.388(\mathrm{CI}: 2.433$ 11.933), artinya risiko untuk mengalami perdarahan post partum pada kelompok jarak kehamilan berisiko ( $<2$ tahun) adalah 5.388 kali lebih besar dibandingkan dengan kelompok jarak kehamilan berisiko ( $<2$ tahun).

\section{Pembahasan}

\section{a. Umur}

Hasil penelitian menunjukkan bahwa responden umur berisiko $(<20$ tahun dan $>35$ tahun) lebih banyak pada kelompok kasus yaitu sebanyak 40 orang $(69,0 \%)$ sedangkan pada kelompok kontrol sebanyak 22 orang (37,9\%). Hasil uji Chi Square didapatkan adanya hubungan yang bermakna antara umur dengan kejadian perdarahan post partum dengan $p$ value: 0,001 dengan nilai $\mathrm{OR}=$ 3.636 (CI: 1.686-7.843), artinya risiko untuk mengalami perdarahan pasca persalinan pada kelompok umur $<20$ tahun dan kelompok umur > 35 tahun adalah 3.636 kali lebih besar dibandingkan dengan kelompok umur 20-35 tahun.

Hasil penelitian ini sesuai dengan beberapa penelitian di luar negeri seperti hasil penelitian Bushra et al. (2007) bahwa pada tingkat kepercayaan $95 \%$ ibu yang berumur di bawah 20 tahun atau di atas 30 tahun memiliki risiko mengalami perdarahan post partum 3,3 kali lebih besar dibandingkan ibu yang berumur 20 sampai 29 tahun. Selain itu penelitian Najah (2004) umur ibu di bawah 20 tahun dan di atas 35 tahun bermakna sebagai faktor risiko yang mempengaruhi perdarahan postpartum.

Penelitian ini sejalan dengan penelitian Pardosi (2005) di Puskesmas Kota Medan menjelaskan bahwa terdapat hubungan yang signifikan antara umur dengan kejadian perdarahan post partum dengan pvalue 0,009 dan umur ibu kurang dari 20 tahun dan lebih dari 35 tahun memberikan 3,3 kali risiko terjadinya perdarahan post partum. Penelitian Sheldon, et al. (2014) di Western Australia 
Dinamika Kesehatan Jurnal Kebidanan dan Keperawatan Vol 10 No. 2 Desember 2019 ( ISSN: 2086-3454 EISSN: 2549-4058)

url: http://ojs.dinamikakesehatan.unism.ac.id DOI: https://doi.org/10.33859/dksm.v10i2

Faktor- Faktor Yang Berhubungan Dengan Kejadian Perdarahan Postpartum Pada Ibu Bersalin di Wilayah Kerja Dinas Kesehatan Kabupaten Merangin

menjelaskan bahwa faktor-faktor yang secara signifikan terkait dengan diagnosis perdarahan postpartum adalah usia, paritas, usia kehamilan, induksi persalinan, dan wilayah geografis.

Hasil penelitian Kurniawan et al. (2017) yang dilakukan di Rumah Sakit Umum Anutapura Palu, didapatkan bahwa ibu umur 35 tahun memiliki berisiko 2,138 kali lebih besar untuk mengalami perdarahan postpartum dibandingkan ibu dengan umur 20-35 tahun.

Menurut Setiawan (2019) umur reproduksi yang ideal bagi wanita untuk hamil dan melahirkan adalah 20-35 tahun, hal ini disebabkan karena umur kurang dari 20 tahun perkembangan rahim dan panggul ibu belum cukup dewasa untuk menjadi ibu, sedangkan pada umur 35 tahun keatas elastisitas otot-otot panggul dan telah mengalami kemunduran alat-alat reproduksi sehingga dapat mempersulit persalinan dan selanjutnya dapat menyebabkan kematian pada ibu
Gordon et al. (2008) menjelaskan bahwa seorang wanita jika ingin memiliki kesehatan reproduksi yang prima seharusnya menghindari "4 terlalu" dimana dua diantaranya adalah menyangkut dengan umur ibu. T yang pertama yaitu terlalu muda artinya hamil pada umur kurang dari 20 tahun. Adapun risiko yang mungkin terjadi jika hamil di bawah 20 tahun antara lain keguguran, preeklampsia (tekanan darah tinggi, oedema, proteinuria), eklampsia (keracunan kehamilan), timbulnya kesulitan persalinan karena sistem reproduksi belum sempurna, bayi lahir sebelum waktunya, Berat Badan Lahir Rendah (BBLR), fistula vesikovaginal (merembesnya air seni ke vagina), fistula retrovaginal (keluarnya gas dan tinja dari vagina) dan kanker leher rahim. $\mathrm{T}$ yang kedua adalah terlalu tua artinya hamil diatas umur 35 tahun, risiko yang mungkin terjadi jika hamil (Manuaba, 2009).

Risiko pada umur terlalu tua ini antara lain adalah terjadinya keguguran, preeklampsia, eklampsia, timbulnya kesulitan pada persalinan, perdarahan, BBLR dan cacat 
Dinamika Kesehatan Jurnal Kebidanan dan Keperawatan Vol 10 No. 2 Desember 2019 ( ISSN: 2086-3454 EISSN: 2549-4058)

url: http://ojs.dinamikakesehatan.unism.ac.id DOI: https://doi.org/10.33859/dksm.v10i2

Faktor- Faktor Yang Berhubungan Dengan Kejadian Perdarahan Postpartum Pada Ibu Bersalin di Wilayah Kerja Dinas Kesehatan Kabupaten Merangin

bawaan.Kematian maternal pada ibu yang hamil dan melahirkan pada umur $<20$ tahun dan umur $>35$ tahun akan meningkat secara bermakna, karena mereka terpapar pada komplikasi baik medis maupun obstetrik yang dapat membahayakan jiwa ibu, sehingga mengapa umur berpengaruh sebagai penyebab perdarahan post partum (Manuaba, 2009).

Perdarahan post partum yang mengakibatkan kematian maternal pada wanita hamil yang melahirkan pada umur dibawah 20 tahun 2-5 kali lebih tinggi daripada perdarahan pascapersalinan yang terjadi pada umur 20-29 tahun. Perdarahan pasca persalinan meningkat kembali setelah umur 30-35 tahun (Magann et al.,2007).

Menurut peneliti tingginya jumlah ibu hamil dengan usia berisiko didukung oleh fakta yang menyebutkan bahwa masih banyak wanita dengan usia pernikahan di bawah 20 tahun di kabupaten Merangin. Hal ini menyebabkan adanya ibu yang hamil sebelum usia 20 tahun sebanyak 11 orang pada kelompok kasus dan dan 7 orang pada kelompok kontrol. Pendewasaan usia pernikahan dapat membantu untuk menurunkan angka kehamilan dibawah usia 20 tahun dan diharapkan dapat menurunkan risiko perdarahan postpartum. Selain itu pada penelitian ini juga ditemukan ibu hamil yang berusia lebih dari 35 tahun. Hasil wawancara dengan responden yang berusia > 35 tahun menyatakan bahwa mereka rata-rata menyebutkan bahwa kehamilan ini tidak direncanakan khususnya karena penggunaan alat kontrasepsi yang gagal. Responden menyatakan alat kontrasepsi yang digunakan bervariasi yaitu metode suntik dan pil. Alasan lain yang dikemukan responden yaitu mereka memang menginginkan untuk punya anak lagi. Tentunya alasan-alasan yang dikemukakan harus diantisipasi dengan meningkatkan pengetahuan responden oleh tenaga kesehatan di tingkat pelayanan primer.

\section{b. Paritas}

Hasil penelitian menunjukkan bahwa paritas berisiko (1 dan >4) sebanyak 44 responden $(75,9 \%)$ sedangkan pada kelompok kontrol sebanyak 20 responden 
Dinamika Kesehatan Jurnal Kebidanan dan Keperawatan Vol 10 No. 2 Desember 2019 ( ISSN: 2086-3454 EISSN: 2549-4058)

url: http://ojs.dinamikakesehatan.unism.ac.id DOI: https://doi.org/10.33859/dksm.v10i2

Faktor- Faktor Yang Berhubungan Dengan Kejadian Perdarahan Postpartum Pada Ibu Bersalin di Wilayah Kerja Dinas Kesehatan Kabupaten Merangin

$(34,5 \%)$ paritas berisiko (1 dan >4). Hasil uji

Chi-Square ditemukan adanya hubungan

yang bermakna antara paritas dengan

kejadian perdarahan postpartum dengan nilai

$p$ Value adalah 0,000, nilai $\mathrm{OR}=5.971(\mathrm{CI}$ :

2.658-13.413), artinya risiko untuk

mengalami perdarahan post partum pada

kelompok paritas berisiko (1 dan >4) adalah

5.971 kali lebih besar dibandingkan dengan

kelompok paritas tidak berisiko (2 dan 3).

Penelitian ini sejalan dengan

penelitian Suryani (2008) di RSUD

Pringgodani Medan yang menjelaskan bahwa ada hubungan paritas dengan kejadian perdarahan post partum dengan $p$ value 0,002 dan $\mathrm{OR}=3,571$.

Arifin et al. (2012) perdarahan postpartum dapat terjadi pada multiparitas karena adanya relaksasi abnormal uterus. Hasil penelitian yang telah dilakukan oleh Polly et al. (2009) menunjukkan bahwa wanita primipara dan grande multipara memiliki kehilangan darah sama besarnya pada pendarahan postpartum, wanita grande multipara mengalami kehilangan darah terbesar dibandingkan dengan wanita nullipara. Pada penelitian ini terdapat 17 responden primipara pada kelompok kasus dan 21 orang responden dengan grande multipara.

Paritas mempunyai pengaruh terhadap kejadian perdarahan postpartum karena pada setiap kehamilan dan persalinan terjadi perubahan serabut otot pada uterus yang dapat menurunkan kemampuan uterus untuk berkontraksi sehingga sulit untuk melakukan penekanan pembuluh - pembuluh darah yang membuka setelah lepasnya plasenta. Risiko terjadinya akan meningkat setelah persalinan ketiga atau lebih yang mengakibatkan terjadinya perdarahan postpartum (Polly et al., 2009).

Paritas adalah jumlah kehamilan yang memperoleh janin yang dilahirkan. Paritas yang tinggi memungkinkan terjadinya penyulit kehamilan dan persalinan diantaranya dapat menyebabkan terganggunya transport $\mathrm{O} 2$ dari ibu ke janin sehingga terjadi asfiksia yang dapat dinilai 
Dinamika Kesehatan Jurnal Kebidanan dan Keperawatan Vol 10 No. 2 Desember 2019 ( ISSN: 2086-3454 EISSN: 2549-4058)

url: http://ojs.dinamikakesehatan.unism.ac.id DOI: https://doi.org/10.33859/dksm.v10i2

Faktor- Faktor Yang Berhubungan Dengan Kejadian Perdarahan Postpartum Pada Ibu Bersalin di Wilayah Kerja Dinas Kesehatan Kabupaten Merangin

dari APGAR Score menit pertama setelah lahir (Manuaba, 2010).

Paritas/jumlah kehamilan 2 sampai 3 adalah paritas yang paling aman dilihat dari sudut kematian ibu. Paritas satu dan umur ibu terlalu muda di kategorikan berisiko tinggi karena ibu belum siap secara mental maupun secara medis sedangkan paritas diatas empat dan umur ibu terlalu tua secara fisik ibu mengalami kemunduran untuk menjalani kehamilan. Paritas merupakan faktor risiko yang memengaruhi perdarahan postpartum. Pada paritas yang rendah (paritas 1) dapat menyebabkan ketidaksiapan ibu dalam menghadapi persalinan sehingga ibu hamil tidak mampu dalam menangani komplikasi yang terjadi selama kehamilan, persalinan dan nifas. Sedangkan semakin sering wanita mengalami kehamilan dan melahirkan (paritas lebih dari 3) maka uterus semakin lemah sehingga besar risiko komplikasi kehamilan. Paritas 2-3 merupakan paritas paling aman ditinjau dari sudut perdarahan postpartum yang dapat mengakibatkan kematian maternal. Paritas satu dan paritas tinggi (lebih dari tiga) mempunyai angka kejadian perdarahan postpartum lebih tinggi. Lebih tinggi paritas, lebih tinggi risiko perdarahan post partum. Risiko pada paritas dapat ditangani dengan asuhan obstetrik yang lebih baik, sedangkan risiko pada paritas tinggi dapat dikurangi atau dicegah dengan keluarga berencana. Sebagian kehamilan pada paritas tinggi adalah tidak direncanakan (Manuaba, 2009).

\section{c. Jarak Kehamilan}

Hasil penelitian menunjukkan bahwa jarak kehamilan berisiko ( $<2$ tahun) sebanyak 39 responden $(67,2 \%)$ lebih besar dibandingkan jarak kehamilan tidak berisiko ( $\geq 2$ tahun) pada kelompok kasus sebanyak 19 responden $(32,8 \%)$ sedangkan pada kelompok kontrol yaitu sebanyak 16 responden (27,6\%). Hasil uji statistik Chi-Square menunjukkan ada hubungan yang bermakna antara jarak kehamilan dengan kejadian perdarahan post partum dengan nilai pvalue : 0,000, dengan nilai $\mathrm{OR}=5.388(\mathrm{CI}: 2.433$ 11.933), artinya risiko untuk mengalami perdarahan post partum pada kelompok jarak 
Dinamika Kesehatan Jurnal Kebidanan dan Keperawatan Vol 10 No. 2 Desember 2019 ( ISSN: 2086-3454 EISSN: 2549-4058)

url: http://ojs.dinamikakesehatan.unism.ac.id DOI: https://doi.org/10.33859/dksm.v10i2

Faktor- Faktor Yang Berhubungan Dengan Kejadian Perdarahan Postpartum Pada Ibu Bersalin di Wilayah Kerja Dinas Kesehatan Kabupaten Merangin

kehamilan berisiko adalah 5.388 kali lebih besar dibandingkan dengan kelompok jarak kehamilan tidak berisiko.

Penelitian ini di dukung oleh hasil penelitian Hazmi (2013) yang menyimpulkan bahwa jarak kehamilan berisiko ( $<2$ tahun) memiliki peluang 2,853 kali untuk mengalami perdarahan pasca persalinan. Hazmi menyatakan bahwa jarak kehamilan yang terlalu dekat dengan kehamilan sebelumnya, memiliki banyak risiko yang dapat menimpa baik ibu maupun janin.

Penelitian ini sesuai dengan penelitian yang dilakukan Rifdiani (2014) tentang pengaruh paritas, BBL, jarak kehamilan dan riwayat persalinan terhadap kejadian perdarahan postpartum di Blitar menemukan bahwa jarak kehamilan berpengaruh dengan kejadian perdarahan postpartun dengan nilai $\mathrm{OR}=17,953 ; \mathrm{CI} 95 \% 3,550<\mathrm{OR}<90,785$.

Jarak kehamilan yang terlalu dekat berisiko terhadap keadaan ibu dan janin, karena setelah melahirkan seorang wanita akan mengalami proses pemulihan alat reproduksi bagian dalam kearah keadaan seperti sebelum hamil. Keadaan rahim atau uterus sebenarnya akan pulih kembali 6 bulan setelah melahirkan akan tetapi fungsinya belum bekerja secara maksimal dan persalinan yang berturut-turut dalam jangka waktu yang singkat akan mengakibatkan kontraksi uterus menjadi kurang baik (Rochjati,2015).

Rahim yang masih belum pulih akibat persalinan sebelumnya belum bisa memaksimalkan pembentukan cadangan makanan bagi janin dan untuk ibu sendiri. Akibatnya akan berdampak tidak baik bagi ibu maupun bayinya. Bagi ibu sendiri meningkatkan risiko terkena anemia akut. Ibu hamil yang terkena anemia akut akan meningkatkan risiko terhadap komplikasi kehamilan, bayi terlahir prematur, risiko perdarahan saat persalinan dan risiko terburuk yaitu keguguran (Suririnah, 2009).

Menurut Ridfiani (2017) jarak antara dua kehamilan dan kelahiran yang paling baik adalah 2-4 tahun. Namun pada penelitian ini masih ditemukan jarak kehamilan $<2$ tahun pada kelompok kasus yaitu sebanyak 27 
Dinamika Kesehatan Jurnal Kebidanan dan Keperawatan Vol 10 No. 2 Desember 2019 ( ISSN: 2086-3454 EISSN: 2549-4058)

url: http://ojs.dinamikakesehatan.unism.ac.id DOI: https://doi.org/10.33859/dksm.v10i2

Faktor- Faktor Yang Berhubungan Dengan Kejadian Perdarahan Postpartum Pada Ibu Bersalin di Wilayah Kerja Dinas Kesehatan Kabupaten Merangin

responden dan pada kelompok kontrol sebanyak 13 responden. Jarak kelahiran yang ideal adalah 2 tahun atau lebih karena jarak kelahiran yang pendek akan menyebabkan seorang ibu belum cukup waktu untuk memulihkan keadaan tubuhnya setelah melahirkan. Setelah melahirkan seorang ibu akan mengalami masa puerperium atau masa nifas untuk mengembalikan alat reproduksi bagian dalam ke keadaan seperti semula atau normal (Ridfiani, 2017).

Jarak kehamilan yang pendek secara langsung akan memberikan efek terhadap kesehatan wanita maupun kesehatan janin yang dikandungnya. Seorang wanita setelah bersalin membutuhkan waktu 2 sampai 3 tahun untuk memulihkan tubuhnya dan mempersiapkan diri untuk kehamilan dan persalinan berikutnya. Bila jarak kehamilan terlalu dekat, rahim yang masih belum pulih benar akibat persalinan sebelumnya belum bisa memaksimalkan pembentukan cadangan makanan bagi janin dan untuk ibu sendiri. Akibatnya akan berdampak tidak baik bagi ibu maupun bayinya. Bagi ibu sendiri meningkatkan risiko terkena anemia akut. Ibu hamil yang terkena anemia akut akan meningkatkan risiko terhadap komplikasi kehamilan, bayi terlahir prematur, risiko perdarahan saat persalinan dan risiko terburuk yaitu keguguran (Rochjati,2012).

Selain pemulihan alat reproduksi, ibu juga dalam keadaan menyusui yang wajib menyusui ASI eksklusif, karena pemberian ASI eksklusif ini dapat membantu mempercepat proses pemulihan alat reproduksi ibu bagian dalam. Pada saat menyusui bayi isapan bayi merangsang hipofisis posterior sehingga oksitosin dapat keluar yang dapat merangsang kerja otot uterus. Waktu ideal pemebrian ASI adalah enam bulan pertama dan dilanjutkan sampai anak berusia 2 tahun, sehingga jarak persalinan $>2$ tahun adalah waktu ideal ibu untuk hamil lagi selain untuk memulihkan juga untuk memaksimalkan pemberian ASI pada ibu.

Masih banyaknya responden dengan jarak kehamilan yang tidak sesuai dengan rekomendasi para ahli menunjukkan bahwa 
Dinamika Kesehatan Jurnal Kebidanan dan Keperawatan Vol 10 No. 2 Desember 2019 ( ISSN: 2086-3454 EISSN: 2549-4058)

url: http://ojs.dinamikakesehatan.unism.ac.id DOI: https://doi.org/10.33859/dksm.v10i2

Faktor- Faktor Yang Berhubungan Dengan Kejadian Perdarahan Postpartum Pada Ibu Bersalin di Wilayah Kerja Dinas Kesehatan Kabupaten Merangin

program keluarga berencana belum lagi

optimal, oleh karena itu beberapa langkah dapat dilakukan seperti edukasi $\mathrm{KB}$ selama kehamilan sehingga ibu hamil memiliki waktu yang panjang untuk berdiskusi dengan keluarga dan pada saat post partum, ibu sudah memutuskan akan memakai alat kontrasepsi yang akan digunakan tentunya yang sesuai dengan kebutuhan ibu.

\section{Ucapan Terima Kasih}

Penulis mengucapkan terima kasih kepada kepala dinas kesehatan kabupaten merangin, pimpinan Puskesmas dan Bidan Desa di wilayah kerja dinas kesehatan Merangin, atas izin yang diberikan kepada penulis dan kesediaan untuk berpartisipasi dalam penelitian ini.

\section{Daftar Pustaka}

Arifin I.M.I (2012). Faktor-faktor penyebab perdarahan postpartum pada ibu bersalin di RSUD panembahan senopati Bantul Yogyakarta. Thesis. Universitas Jenderal Achmad Yani : Yogyakarta

Assarag B, Dubourg D, Maaroufi A, Dujardin B, dan Brouwere VD. (2013). Maternal Postpartum Morbidity in Marrakech: what women feel what doctors diagnose

Azwar, S. (2012). Metodologi Penelitian. Pustaka Pelajar. Yogyakarta

Bushra, Z.S (2007). Risk Factors for Primary Postpartum Haemorrage

Calvert C, Thomas SL, Ronsmans C, Wagner KS, Adler AJ, Filippi V. (2012).Identifying regional variation in the prevalence of postpartum haemorrhage: a systematic review and metaanalysis. PLoS One. Volume 7( 7.) Pp.1-10. doi: 0.1371/journal.pone.0041114

Cunningham, F.G. (2012). Obstetri Williams (edisi 23). Jakarta: EGC.

Dinas Kesehatan Provinsi Jambi. (2016). Profil Kesehatan Provinsi Jambi: Dinas Kesehatan Provinsi Jambi.

Dinkes Kabupaten Merangin. (2018). Laporan pencapaian indikator KIA dan gizi kabupaten merangin tahun 2018. Bangko. doi.org/10.1097/01.SMJ.00001527 60.34443.86. 
Dinamika Kesehatan Jurnal Kebidanan dan Keperawatan Vol 10 No. 2 Desember 2019 ( ISSN: 2086-3454 EISSN: 2549-4058)

url: http://ojs.dinamikakesehatan.unism.ac.id DOI: https://doi.org/10.33859/dksm.v10i2

Faktor- Faktor Yang Berhubungan Dengan Kejadian Perdarahan Postpartum Pada Ibu Bersalin di Wilayah Kerja Dinas Kesehatan Kabupaten Merangin

Gordon D et al. (2008) Advanced Maternal Age As A Risk Factor For Cesarean Delivery. Journal Obstetric Gynecollogyc. Vol. 77(4). pp.493497.

Hazmi S .(2013). Faktor-Faktor Yang Mempengaruhi Kejadian Perdarahan Post-partum Di RSUD Panembahan Seno-pati. Skripsi. Sekolah Tinggi Ilmu Ksehatan Aisyiyah Yogyakarta. Yogyakarta.

Kemenkes RI. (2015). Profil Kesehatan Indonesia 2014. Jakarta : Kementrian Kesehatan Republik Indonesia.

Kemenkes RI. (2017). Profil Kesehatan Indonesia 2016. Jakarta : Kementrian Kesehatan Republik Indonesia.

Magann, Everett F, et al. (2005). Postpartum Hemorrhage after vaginal birth. An analysis of Risk Factors Southern Medical Assosiation. Volume 98(4).pp.1-4.

Manuaba,I.B.G. (2010). Gawat Darurat Obstetri Ginekologi dan Obstretri ...Ginekologi Sosial untuk Profesi Bidan. Jakarta: EGC

Najah, SN. 2004. Beberapa Karakterisitik Ibu yang Berpengaruh Terhadap Kejadian Perdarahan Postpartum (Studi Kasus pada Bulan Januari September 2003 di RSUD DR. H. Soewondo Kendal). Tesis. Semarang: Universitas Diponegoro.

Pardosi, M. 2005. Analisis Faktor-Faktor yang Berhubungan dengan Perdarahan Pasca Persalinan dan Upaya Penurunannya di Wilayah Kerja Puskesmas Kota Medan Tahun 2009. Tesis. Medan: FKM USU
Polly et al. (2009). Incidence of postpartum hemorrhage. US Jounal Medical, Vol.346 (26). Pp. 1-10.

Profesional Med J 14 (3): 378-379. DOI: $10.1007 / \mathrm{BF} 02505330$.

Ridfiani, I. (2017). Pengaruh Paritas, BBL, Jarak Kehamilan Dan Riwayat Perdarahan Terhadap Kejadian Perdarahan Postpartum

Rocjati P. (2015). Skrining Antenatal Pada Ibu Hamil. Majalah Obstetri dan Ginekologi. Volume 23 (1). pp.2832.

Saadah, et al. (2013). Multilevel Analysis on the Risk Factors of Post Partum Hemorrhage in Bondowoso. Journal of Maternal and Child Health. Volume 1(4). 2016. Pp. 205 